\title{
Research Paper: The Value of Foramen Magnum Diameters for Gender Identification Among Iranian Population
}

\author{
Siamak Soltani $^{1}$ (D), Kamran Aghakhani ${ }^{1}$ (D) Hanieh Saboori-Shekofte ${ }^{1}$ (D), Sahar Rismantab-Sani² , Forouzan Faress $^{1}$ (D), Tayebe Khayamdar ${ }^{1 *}$ (D)
}

1. Department of Forensic Medicine, School of Medicine, Iran University of Medical Sciences, Tehran, Iran.

2. Department of Gastroenterology, School of Medicine, Ramsar Campus, Mazandaran University of Medical Sciences, Ramsar, Iran.

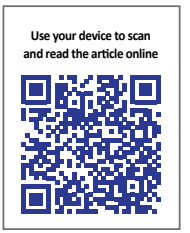

Citation: Soltani S, Aghakhani K, Saboori-Shekofte H, Rismantab-Sani S, Faress F, Khayamdar T. The Value of Foramen Magnum Diameters for Gender Identification Among Iranian Population. International Journal of Medical Toxicology and Forensic Medicine. 2019; 9(4):205-212. https://doi.org/10.32598/ijmtfm.v9i4.25367

dof https://doi.org/10.32598/ijmtfm.v9i4.25367

Article info:

Received: 13 Jan 2019

First Revision: 25 Feb 2019

Accepted: 23 Jun 2019

Published: 01 Oct 2019

\section{Keywords:}

Foramen magnum, Gender identification, Iranian population

\section{ABSTRACT}

Background: By assessing the size of the foramen magnum, it is possible to distinguish two genders, as well as the intergenerational interdependence of the affected individuals. The present study aimed at assessing the value of diameters of foramen magnum for gender identification among the Iranian population.

Methods: This analytical comparative cross-sectional study was performed on 200 Iranian cadavers (100 men and 100 women) referred to Kahrizak Autopsy Hall in Tehran between 2017 and 2018. In each case, the foramen magnum was measured by observation and its parameters were measured in a longitudinal anteroposterior and transverse diameter, using a calibrated caliper.

Results: The Mean \pm SD anterior-posterior diameter of the foramen magnum in men and women were $35.59 \pm 0.49 \mathrm{~mm}$ and $33.90 \pm 1.07 \mathrm{~mm}$, respectively, which was significantly higher in men $(\mathrm{P}<0.001)$. Similarly, the Mean $\pm \mathrm{SD}$ transverse diameter of the foramen magnum in males and females was $29.49 \pm 0.56 \mathrm{~mm}$ and $28.5 \pm 0.50 \mathrm{~mm}$, respectively, which was significantly higher in men $(\mathrm{P}<0.001)$. Based on the area analysis under the Receiver Operating Characteristic (ROC) curve, the anterior-posterior and transverse diameters of the foramen magnum had a high value in the differentiation of the male and female genders (AUC $=0.953$ and 0.896 , respectively, $\mathrm{P}<0.001$ ). The Mean $\pm \mathrm{SD}$ foramen magnum index in men and women was $84.15 \pm 3.02$ and $82.87 \pm 1.95$, respectively, which had a significant difference between the two genders.

Conclusion: Given that the anterior-posterior and transverse diameters of the foramen magnum in Iranian men are far more than Iranian women, these diameters can be used to distinguish between the two genders in the precise legal field.

* Corresponding Author:

Tayebe Khayamdar, PhD.

Address: Department of Forensic Medicine, School of Medicine, Iran University of Medical Sciences, Tehran, Iran.

Tel: +98 (912) 5497355

E-mail: tayebekhayamdar9@gmail.com 


\section{Introduction}

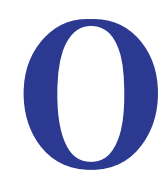

ne of the essential requirements for corpse examination in forensic science is the recognition of identity and the identification using human skeletons is one of the legal skills of medical records [1]. Gender determination is one of the most important issues of identification. If all the skeletons of an individual are available, gender determination is not a problem and $100 \%$ of gender determination can be achieved with a complete skeleton [1]. However, sometimes there are only remnants of the human skeleton or fragments of the collapsed skeleton; for example, in air accidents, natural disasters, fire or mutilation, in which gender determination is not easy [2]. Scientists in this field are always looking for a way to solve this problem and find a sign of authentication in these cases. As a solution in these cases, experts in this field try to use the biological features of the human skeleton to determine gender [3].

Skull is the most convenient part of the skeleton for gender determination [1]. The human skeleton may have remained for centuries and one of the most resilient parts in the human skeletons is foramen magnum in the skull base. The foramen magnum is a large foramen in the skull base, which according to studies shows that the parameters of this foramen are useful in determining gender [4]. This foramen is a useful mark on the base of the skull, and its intuitive shape can be useful in identifying race and identity [5].

In addition to the importance of understanding the foramen magnum anatomy and its variations in the treatment of various types of diseases, it can be very important to evaluate these variances in the distinction between the two genders $[6,7]$. Foramen magnum diameters are, therefore, used in forensic and anthropological methods to determine the gender of the human embryo [8-10]. It is worth noting that the area of the foramen magnum is completely covered by soft tissue mass. Therefore, the foramen magnum area should be evaluated by assessing changes in its soft tissue coverage. In total, the morphometric analysis of this foramen is highly diagnostic and useful in cases of traumatic injuries, accidents, and even fires. In fact, thanks to the major changes in these diameters in these injuries, it is sometimes possible to detect the gender of deceased persons only through some indicators, such as evaluating the magnitudes of the foramen magnum $[11,12]$. In some studies, the foramen magnum diameters have been used to identify gender in cadavers $[13,14]$.
In total, it has been determined that the anterior-posterior and transverse diameters of the foramen magnum, in general, are higher in males than females $[15,16]$. In some cases, the structural difference in foramen magnum in different races has been also shown [17]. Also, the relationship between the foramen magnum diameters in a person with the generations of that person is shown [18]. Therefore, by assessing the size of this foramen, it is possible to distinguish between two genders, as well as the intergenerational interdependence of the affected individuals. The present study aimed at assessing the value of diameters of foramen magnum for gender identification among the Iranian population.

\section{Materials and Methods}

This analytical comparative cross-sectional study was performed on 200 Iranian cadavers (100 men and 100 women) referred to Kahrizak Autopsy Hall in Tehran between 2017 and 2018. The subjects were in the age range of 20 to 60 years and included simple consecutive sampling. Cadavers that underwent forensic exploration because of unnatural death or suspected causes of death were included in the study and none was dissected just for the purpose of this study. Cadavers with traumatic injury and fractures in the skull were excluded. In each case, the foramen magnum was measured by observation and its parameters were measured in a longitudinal anteroposterior and transverse diameter, using a calibrated caliper. The foramen magnum index and its area were measured based on the specific formula. The shape of the foramen magnum was determined based on the defined patterns of the exterior check-list as round, oval, pentagon, hexagonal, and irregular with exact observation. The longitudinal diameter of the foramen magnum was measured as the maximum distance between anterior and posterior points of foramen magnum with a digital coulis. The transverse diameter of the foramen magnum was measured as the maximum distance between right and left ends (maximum width) of foramen magnum with a digital coulis. Foramen magnum index and area of foramen magnum were calculated based on the following Formulas 1, 2, 3 and 4:

1. Foramen magnum index $=($ Sagittal diameter $/$ Trans verse diameter $) \times 100$

Area of foramen magnum based on Teixeira's Formula [4]:

2. FM Area $=\pi[($ Sagittal diameter + Transverse $d i-$ ameter) $/ 4]^{2}$

Area of foramen magnum based on Ritual's Formula [4]: 


\section{3. $F M$ Area $=$ Sagittal diameter $\times$ Transverse diameter $\times \pi / 4$}

Average longitudinal and transverse diameter of foramen magnum:

\section{4. (Sagittal diameter + Transverse diameter) $/ 2$}

For statistical analysis, the results were presented as Mean \pm SD for quantitative variables and were summarized by absolute frequencies and percentages for categorical variables. Categorical variables were compared, using the Chi-square test or Fisher's exact test when more than $20 \%$ of the cells with an expected count of less than five were observed. The quantitative variables were also compared with $t$ test or Mann-Whitney $U$ test. To measure the correlation between the values of diameters across the men and women, Pearson's correlation test was used. To assess the difference between men and women regarding foramen magnum diameters with the presence of baseline variables was assessed, using the Multivariable linear regression analysis. For the statistical analysis, the statistical software SPSS V. 16 for windows (SPSS Inc., Chicago, IL) was used. P-values of 0.05 or less were considered statistically significant.

\section{Results}

In this study, 100 male and 100 female samples were studied in terms of foramen magnum indices, including sagittal diameters (anterior-posterior) and transverse diameters. The age of the sample population was between 20 and 60 years old (Table 1). The Mean \pm SD anterior-posterior diameter of the foramen magnum in men and women was $35.59 \pm 0.49 \mathrm{~mm}$ and $33.90 \pm 1.07$ $\mathrm{mm}$, respectively. The Mean $\pm \mathrm{SD}$ transverse diameter of the foramen magnum in males and females was $29.49 \pm 0.56 \mathrm{~mm}$ and $28.50 \pm 0.50 \mathrm{~mm}$, respectively. The Mean \pm SD foramen magnum index in men and women was $82.87 \pm 1.95$ and $84.15 \pm 3.02$, respectively, and the Mean \pm SD foramen magnum area based on Teixeira's Formula in men and women was $831.33 \pm 18.98$ and $764.58 \pm 29.18$, respectively. The Mean \pm SD foramen magnum area based on Ritual's Formula in men and women was $823.92 \pm 19.35$ and $758.59 \pm 27.80$, respectively. All of the calculated parameters were significantly higher in men than women $(\mathrm{P}<0.001)$ (Table 2$)$. Based on the area analysis under the Receiver Operating Characteristic (ROC) curve (Figure 1), all of the indices had high sensitivity and specificity in the differentiation of the male and female genders (Table 3). The association between gender and measured dimensions may be confounded by body mass index (BMI), which was not matched in both groups. To find the independent gender predictors among the measured variables and also to adjust for BMI, Logistic Regression analysis was applied (Table 4). Multivariate Logistic Regression analysis revealed that all of the calculated parameters were independent gender predictors.

\section{Discussion}

Various skeletal indices are used to distinguish genders in cases where gender detection is not possible through the evaluation of soft tissues (especially in the case of burns, traumas, and explosions). In previous studies, the evaluation of parameters such as the length and diameter of the upper and lower limbs, various skull sizes,

Table 1. Comparison of demographic characteristics between genders

\begin{tabular}{|c|c|c|c|c|}
\hline Index & Gender & Mean士SD & $\mathbf{Z 1}$ & $\mathbf{P}$ \\
\hline \multirow{2}{*}{ Sagittal diameter (mm) } & Female & $33.90 \pm 1.07$ & \multirow{2}{*}{-14.37} & \multirow{2}{*}{$<0.001$} \\
\hline & Male & $35.59 \pm 0.49$ & & \\
\hline \multirow{2}{*}{ Transvers diameter(mm) } & Female & $28.50 \pm 0.50$ & \multirow{2}{*}{-13.16} & \multirow{2}{*}{$<0.001$} \\
\hline & Male & $29.49 \pm 0.56$ & & \\
\hline \multirow{2}{*}{ Foramen magnum index } & Female & $82.87 \pm 0.01$ & \multirow{2}{*}{-18.99} & \multirow{2}{*}{$<0.001$} \\
\hline & Male & $84.15 \pm 0.01$ & & \\
\hline \multirow{2}{*}{ Teixeriab formula } & Female & $764.58 \pm 29.18$ & \multirow{2}{*}{-19.28} & \multirow{2}{*}{$<0.001$} \\
\hline & Male & $831.33 \pm 18.98$ & & \\
\hline \multirow{2}{*}{ Ritual's formula } & Female & $758.59 \pm 27.80$ & \multirow{2}{*}{-19.28} & \multirow{2}{*}{$<0.001$} \\
\hline & Male & $823.92 \pm 19.35$ & & \\
\hline \multirow{2}{*}{ Mean of sagittal and transvers diameter } & Female & $31.20 \pm 0.60$ & \multirow{2}{*}{-18.99} & \multirow{2}{*}{$<0.001$} \\
\hline & Male & $32.54 \pm 0.37$ & & \\
\hline
\end{tabular}


Table 2. Comparison of foramen magnum indices between two genders

\begin{tabular}{cccccc}
\hline Characteristics & Gender & Mean \pm SD & Min & Max & 60 \\
\hline \multirow{2}{*}{ Age (Years) } & Male & $40.65 \pm 12.18$ & 20 & 59 \\
BMI & Female & $38.71 \pm 12.08$ & 20 & 35.16 \\
& Male & $26.30 \pm 2.84$ & 21.62 & 0.01 \\
\hline
\end{tabular}

International Journal of

Table 3. The best cut-off point, sensitivity, and specificity

\begin{tabular}{ccccc}
\hline Index & Cut-off Point & Sensitivity (\%) & Specificity (\%) & P \\
\hline Sagittal diameter $(\mathrm{mm})$ & 35.1 & 77 & 96 & $<0.001$ \\
\hline Transvers diameter $(\mathrm{mm})$ & 29.2 & 67 & 92 & $<0.001$ \\
\hline Foramen magnum index & 83.4 & 100 & 91 & $<0.001$ \\
Teixeria formula & 766.445 & 97 & 91 & $<0.001$ \\
\hline Ritual's formula & 789.49 & 97 & 90 & $<0.001$ \\
\hline Mean of sagittal and transvers diameter & 31.45 & 97 & 91 & $<0.001$ \\
\hline
\end{tabular}

short and wide bone diameters, as well as the apparent features of facial bones have led to their confirmation as distinctive indices of male and female. In this study, we examined the diagnostic value of diameters of the foramen magnum, including anterior-posterior diameters, transverse diameter, foramen magnum index, and area of the foramen magnum in male and female. By examining the parameters, their high diagnostic value for gender identification was confirmed, and all of them were significantly higher in men than that of women. Hence, these diameters can be used to distinguish between the two genders in the Iranian population.

The review of the past studies was also fully consistent with the claims of this study but in other human societies. Most of the studies are conducted on the CT scan to evaluate foramen magnum parameters and in a few of them, such as the current study, foramen magnum diameters are calculated on skeleton and cadavers [19].

Table 4. Logistic regression analysis for gender prediction

\begin{tabular}{|c|c|c|c|c|c|c|c|c|c|c|}
\hline \multirow{3}{*}{ Input Variables } & \multicolumn{5}{|c|}{ Univariate Analysis } & \multicolumn{5}{|c|}{ Multivariate Analysis } \\
\hline & \multirow{2}{*}{ Beta } & \multirow{2}{*}{$\begin{array}{l}\text { Odd's } \\
\text { ratio }\end{array}$} & \multirow{2}{*}{$\mathbf{P}$} & \multicolumn{2}{|c|}{$\mathrm{Cl}$} & \multirow{2}{*}{ Beta } & \multirow{2}{*}{$\mathbf{P}$} & \multirow{2}{*}{$\begin{array}{l}\text { Adjusted } \\
\text { Odd's } \\
\text { ratio }\end{array}$} & \multicolumn{2}{|c|}{$95 \% \mathrm{Cl}$} \\
\hline & & & & 0.025 & 0.975 & & & & 0.025 & 0.975 \\
\hline Sagittal diameter (mm) & 1.33 & 3.2 & $<0.001$ & 23.108 & 461.11 & 1.21 & $<0.001$ & 2.93 & 20.87 & 451.8 \\
\hline Transvers diameter (mm) & 1.52 & 4.13 & $<0.001$ & 10.221 & 55.960 & 1.54 & $<0.001$ & 4.42 & 9.70 & 60.77 \\
\hline Foramen magnum index & 0.20 & 0.82 & $<0.001$ & 0.73 & 0.92 & 0.19 & $<0.001$ & 0.82 & 0.73 & 0.92 \\
\hline Teixeria formula & 0.163 & 1.177 & $<0.001$ & 1.112 & 1.245 & 0.15 & $<0.001$ & 1.16 & 1.10 & 1.23 \\
\hline Ritual's formula & 0.151 & 1.163 & $<0.001$ & 1.105 & 1.224 & 0.14 & $<0.001$ & 0.15 & 1.10 & 1.21 \\
\hline $\begin{array}{c}\text { Mean of sagittal and transvers } \\
\text { diameter }\end{array}$ & 1.87 & 4.52 & $<0.001$ & 15.871 & 60.178 & 1.35 & $<0.001$ & 3.62 & 13.73 & 278.165 \\
\hline
\end{tabular}


Table 5. Comparison of foramen magnum indices in different studies

\begin{tabular}{|c|c|c|c|c|c|c|c|c|c|c|c|}
\hline \multirow[t]{2}{*}{ Study } & \multirow[t]{2}{*}{$\begin{array}{l}\text { Type of } \\
\text { Sample }\end{array}$} & \multicolumn{2}{|c|}{$\begin{array}{l}\text { Number of } \\
\text { Samples }\end{array}$} & \multicolumn{2}{|c|}{$\begin{array}{l}\text { Sagittal Diam- } \\
\text { eter }\end{array}$} & \multicolumn{2}{|c|}{$\begin{array}{c}\text { Transverse Diam- } \\
\text { eter }\end{array}$} & \multicolumn{2}{|c|}{$\begin{array}{l}\text { Area of the } \\
\text { Foramen Magnum } \\
\text { (Teixeria Formula } \\
\mathrm{mm}^{3} \text { ) }\end{array}$} & \multicolumn{2}{|c|}{$\begin{array}{c}\text { Foramen Mag- } \\
\text { num Index }\end{array}$} \\
\hline & & Female & Male & Female & Male & Female & Male & Female & Male & Female & Male \\
\hline Current study & skull & 100 & 100 & 33.90 & 35.59 & 28.50 & 29.49 & 764.58 & 831.33 & 82.87 & 84.15 \\
\hline $\begin{array}{c}\text { Soltani et al. } \\
2016 \\
\text { Iran [4] }\end{array}$ & CT scan & 50 & 50 & 34.37 & 37.71 & 28.34 & 31.68 & 773.96 & 946.66 & 82.41 & 83.97 \\
\hline $\begin{array}{l}\text { Edward et al. } \\
2013 \\
\text { Switzerland } \\
{[10]}\end{array}$ & CT scan & 106 & 144 & 36.66 & 38.17 & 31.44 & 32.05 & 812.14 & 887.60 & - & - \\
\hline $\begin{array}{c}\text { Kamath et al. } \\
2015 \\
\text { India [21] }\end{array}$ & skull & 31 & 41 & 30.99 & 33.21 & 25.45 & 26.96 & 630.57 & 715.32 & - & - \\
\hline $\begin{array}{c}\text { Tellioglu et al. } \\
2015 \\
\text { Turkey [19] }\end{array}$ & CT scan & 50 & 50 & 32.99 & 34.73 & 28.40 & 30.47 & - & - & - & - \\
\hline $\begin{array}{c}\text { Uthman et al. } \\
2014 \\
\text { Iraq [1] }\end{array}$ & CT scan & 45 & 43 & 32.90 & 34.90 & 27.30 & 29.50 & 670.20 & 765.20 & - & - \\
\hline $\begin{array}{c}\text { Gapret et al. } \\
2009 \\
\text { U.K [22] }\end{array}$ & skull & 76 & 82 & 34.71 & 35.91 & 29.36 & 30.51 & 731.28 & 783.83 & - & - \\
\hline $\begin{array}{c}\text { Madiam et al. } \\
2017 \\
\text { Saudi Arabia } \\
{[20]}\end{array}$ & CT scan & 100 & 100 & 36.10 & 37.21 & 30.06 & 31.65 & 869.80 & 925.84 & 84.96 & 85.22 \\
\hline
\end{tabular}

International Journal of
Medical Toxicology \& forensic Medicin

In the study of Soltani et al. in 2016, foramen magnum diameters were calculated based on the CT scan in the Iranian population. The sample size was 100 (50 males and 50 females). Sagittal diameter, transverse diameter, foramen magnum index, and foramen magnum area were in a close range with the current study and the minor difference could be because of the method of the measurement [4]. The results are compared in Table 5.

In the study of Tellioglu et al. in Turkey, foramen magnum diameters were evaluated in 100 CT scans [20]. The mean of anterior-posterior diameters, transverse diameter, and cavity surface area was significantly higher

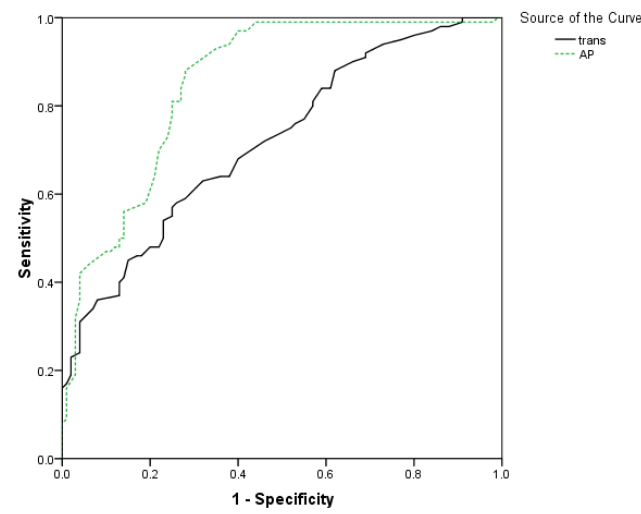

Figure 1. Diagnostic value of foramen magnum diameters in gender differentiation based on ROC curve 
in men than in men (Table 5). They used univariate and multivariate discriminant analysis and revealed that anteroposterior diameter could be able to detect $64 \%$ of women and $70 \%$ of men. In the current study, foramen magnum parameters had an acceptable level of sensitivity and specificity in gender determination (Table 3).

In our study, there was a significant relationship between BMI and gender. To reveal the independent predictor parameters, we used multivariate logistics regression and found all calculated parameters to predict gender notwithstanding BMI (Table 4).

In a study by Madadin et al. in Saudi Arabia, sagittal diameter, transverse diameter, and area of foramen magnum were significantly higher in men than in women. All of the dimensions were greater than what we found in this study. They calculated foramen magnum index 84.96 in women and 85.22 in men. In our study, the foramen magnum index was 82.87 in women and 84.15 in men. This variation could be because of different ethnic groups and suggest that dimensions should be evaluated separately in different societies and races [21]. The study of Kamath et al. in India [22] also showed a significant difference in foramen magnum parameters between two genders (Table 5).

In assessing and comparing the values of foramen magnum dimensions in different societies, we conclude that the measurements of these diameters are very effective in the differentiation of the two genders; also, in different societies and races, they are highly adaptive in the corresponding diameters.

This determines the common origin of all human races in terms of the growth and development of skeletal structures. The techniques of measuring the corresponding diameters (using manual methods or using advanced imaging techniques), as well as the inclusion criteria, are very effective in measuring these indices in various studies. Therefore, in determining the final limits for cranial diameters in different societies and in order to achieve comprehensive human diameters, the use of common measurement techniques and the alignment of the inclusion criteria are necessary.

\section{Conclusion}

As a general conclusion, given that the anterior-posterior and transverse diameters of the foramen magnum, foramen magnum index, and area of the foramen magnum in Iranian men are far more than Iranian women, these diameters can be used to distinguish between the two genders in the precise legal field.

\section{Ethical Considerations}

\section{Compliance with ethical guidelines}

The research protocol was approved by the Ethics Committee of the Iran University of Medical Sciences, Tehran, Iran. The approval number: IR,IUMS,FMD,R EC,139609511223005.

\section{Funding}

This research was extracted from the MD. thesis of Tayebe Khayamdar in the Department of Forensic Legal Medicine, Hazrat Rasul Akram Hospital, Iran University of Medical Sciences, Tehran.

\section{Author's contributions}

Data gathering and data preparation: Siamak Soltani, Tayebe Khayamdar, and Foroozan Fares; Designing and conducting the research, performing the statistical analyses, participating in all stages of the research, preparing, and editing the manuscript: Siamak Soltani and Kamran Aghakhani; Designing and conducting the research and correcting the English manuscript: Hanieh Saboorishekofte, Siamak Soltani, Tayebe Khayamdar, and Sahar Rismantab-sani; and Reading and approving the content of the manuscript: Siamak Soltani, Tayebe Khayamdar, Kamran Aghakhani, Hanieh Saboori-Shekofte, Sahar Rismantab-sani, and Foroozan Fares.

\section{Conflicts of interest}

The authors declared no conflict of interest.

\section{Acknowledgments}

The authors wish to express appreciation to Legal Medicine Orgaanization of Iran (Tehran autopsy hall) for collaborating in collecting samples.

\section{References}

[1] Uthman AT, Al-Rawi NH, Al-Timimi JF. Evaluation of foramen magnum in gender determination using helical CT scanning. Dentomaxillofacial Radiology. 2012; 41(3):197-202. [DOI:10.1259/dmfr/21276789] 
[2] Günay Y, Altinkök M. The value of the size of foramen magnum in sex determination. Journal of Clinical Forensic Medicine. 2000; 7(3):147-9. [DOI:10.1054/jcfm.2000.0430] [PMID]

[3] Krishan K, Chatterjee PM, Kanchan T, Kaur S, Baryah N, Singh RK. A review of sex estimation techniques during examination of skeletal remains in forensic anthropology casework. Forensic Science International. 2016; 261:165-e1-e8. [DOI:10.1016/j.forsciint.2016.02.007] [PMID]

[4] Aghakhani K, Kazemzadeh N, Ghafurian F, Soltani B, Soltani S. Gender determination using diagnostic values of foramen magnum. International Journal of Medical Toxicology and Forensic Medicine. 2016; 6(1):29-35. [DOI:10.22037/ ijmtfm.v6i1(Winter).9503]

[5] Poonamjeet L, Ongeti K, Pulei A, Ogengo J, Mandela P. Gender related patterns in the shape and dimensions of the foramen magnum in an adult Kenyan population. Anatomy Journal of Africa. 2013; 2(2):138-41.

[6] Kanodia G, Parihar V, Yadav YR, Bhatele PR, Sharma D. Morphometric analysis of posterior fossa and foramen magnum. Journal of Neurosciences in Rural Practice. 2012; 3(3):261-6. [DOI:10.4103/0976-3147.102602] [PMID] [PMCID]

[7] Standarding S. Gray's anatomy: The anatomical basis of clinical practice. London: Elsevier Churchill Livingstone; 2005.

[8] Kanchan T, Gupta A, Krishan K. Craniometric analysis of foramen magnum for estimation of sex. International Journal of Medical, Health, Biomedical and Pharmaceutical Engineering. 2013; 7(7):111-3.

[9] Suazo Galdames IC, Perez Russo P, Zavando Matamala DA, Smith RL. Sexual dimorphism in the foramen magnum dimensions. International Journal of Morphology. 2009; 27(1):21-3. [DOI:10.4067/S0717-95022009000100003]

[10] Edwards K, Viner MD, Schweitzer W, Thali MJ. Sex determination from the foramen magnum. Journal of Forensic Radiology and Imaging. 2013; 1(4):186-92. [DOI:10.1016/j. jofri.2013.06.004]

[11] Manoel CC, Prado FB, Caria PH, Groppo FC. Morphometric analysis of the foramen magnum in human skulls of Brazilian individuals: Its relation to gender. Brazilian Journal for Morphological Sciences. 2009; 26(2):104- 8.

[12] Shepur MP, Magi M, Nanjundappa B, Havaldar PP, Gogi $\mathrm{P}$, Saheb SH. Morphometric analysis of foramen magnum. International Journal of Anatomy and Research. 2014; 2:249-55.

[13] Holland TD. Sex determination of fragmentary crania by analysis of the cranial base. American Journal of Physical Anthropology. 1986; 70(2):203-8. [DOI:10.1002/ajpa.1330700207] [PMID]

[14] Graw M. [Morphometrische und morphognostische Geschlechtsdiagnostik an der menschlichen Schadelbasis (German)]. Osteologische Identifikation und Altersschatzung. 2001:103-21.

[15] Barut NR, Kale AN, Turan Suslu HK, Ozturk A, Bozbuga M, Sahinoglu K. Evaluation of the bony landmarks in transcondylar approach. British Journal of Neurosurgery. 2009; 23(3):276-81. [DOI:10.1080/02688690902814725] [PMID]

[16] Furtado SV, Thakre DJ, Venkatesh PK, Reddy K, Hegde AS. Morphometric analysis of foramen magnum dimensions and intracranial volume in pediatric Chiari I malformation.
Acta Neurochirurgica. 2010; 152(2):221-7. [DOI:10.1007/ s00701-009-0480-5] [PMID]

[17] Howale DS, Bathija A, Gupta S, Pandit DP. Correlation between cranial index and foramen magnum index in human dried skulls. Global Journal For Research Analysis. 2014; 3(1):3-6. [DOI:10.15373/22778160/January2014/65]

[18] Kumar A, Dave M, Anwar S. Morphometric evaluation of foramen magnum in dry human skulls. International Journal of Anatomy and Research. 2015; 3(2):1015-23. [DOI:10.5137/1019-5149.JTN.4297-11.1] [PMID]

[19] Singh PK, Tamrakar D, Karki S, Menezes RG. Determination of sex from the foramen magnum using 3DCT: A nepalese study. Kathmandu University Medical Journal. 2017; 15(57):62-6.

[20] Tellioglu AM1, Durum Y, Gok M, Karakas S, Polat AG, Karaman CZ. Suitability of foramen magnum measurements in sex determination and their clinical significance. Folia Morphologica. 2018; 77(1):99-104. [DOI:10.5603/FM.a2017.0070] [PMID]

[21] Madadin M, Menezes RG, Al Saif HS, Alola HA, Al Muhanna A, Gullenpet AH, et al. Morphometric evaluation of the foramen magnum for sex determination: A study from Saudi Arabia. Journal of Forensic and Legal Medicine. 2017; 46:66-71. [DOI:10.1016/j.jflm.2017.01.001] [PMID]

[22] Kamath VG, Asif M, Shetty R, Avadhani R. Binary logistic regression analysis of foramen magnum dimensions for sex determination. Anatomy Research International. 2015 2015(459428):1-9. [DOI:10.1155/2015/459428] [PMID] [PMCID] 
This Page Intentionally Left Blank 